\title{
Ultrastructure of Epithelium of Terminal Bronchioles in Rabbits after Inhalation of Mineral Water Aerosol
}

\author{
J. UHLÍK ${ }^{1}$, V. KONRÁDOVÁ ${ }^{1}$, L. VAJNER ${ }^{1}, J_{\text {. ADÁŠKOVÁ }}^{2}$ \\ ${ }^{1}$ Institute of Histology and Embryology, $2^{\text {nd }}$ Medical Faculty, Charles University, Prague \\ ${ }^{2}$ Institute of Applied Mathematics and Information Technologies, Faculty of Science, Charles University, Prague
}

\author{
Received June 4, 2002
}

Accepted July 23, 2002

\section{Abstract}

Uhlík J., V. Konrádová, L. Vajner, J. Adášková: Ultrastructure of Epithelium of Terminal Bronchioles in Rabbits after Inhalation of Mineral Water Aerosol. Acta Vet. Brno 2002, 71: $283-288$.

Inhalation of mineral water aerosols is a widely used supplementary therapeutic method during the treatment of chronic respiratory diseases. We decided to proceed our previous experiments dealing with the effect of a short-time inhalation of this aerosol on the tracheal epithelium by the evaluation of reaction of the epithelium in distal airways - terminal bronchioles. Laboratory rabbits inhaled an aerosol of special mineral water for $10 \mathrm{~min}$ and material for the electron microscopic examination was collected immediately after inhalation. The ultrastructure of the epithelium of terminal bronchioles was evaluated quantitatively. Computer image analysis was used in the evaluation of cytoplasm of Clara cells. As in control animals, terminal bronchioles of rabbits exposed to 10-min inhalation of the mineral water aerosol were lined with simple columnar epithelium composed of ciliated and Clara cells. On the apical surfaces of ciliated cells, formation of cytoplasmic protrusions leading sometimes to a degeneration of free cilia was recorded. In deeper layers of their cytoplasm, mild marks of the pathological alteration were observed. In secretory Clara cells, tendency to increased proliferation was recorded. This proliferation was not accompanied by elevated liberation of the secretion stored in secretory granules. Only few Clara cells revealed signs of the pathological alteration, their degeneration was not recorded. The findings of the pathological alteration of the epithelial cell cytoplasm and their increased proliferation testify that the homeostasis of the epithelium was damaged and admonish to the heedfulness in the indication even of such seemingly harmless therapeutic procedures.

Airways, ciliated cells, Clara cells, electron microscopy, therapeutic method

Inhalation of mineral water aerosols belongs to usual procedures in the treatment of chronic respiratory disorders. Practical physicians indicating this therapeutic method believe, that special components of selected springs play a crucial role in the treatment. As we found only one very old article dealing with the reaction of respiratory tract on the mineral water inhalation (Vaskivskyj 1968), we started to concentrate on the evaluation of the ultrastructural and histochemical changes of the airway epithelium after the mentioned therapeutic procedure. In our previous study, we demonstrated that a single 10min inhalation of a special mineral water aerosol used in a clinical practice causes statistically significant changes of the ultrastructure of rabbits' tracheal epithelial cells and of the chemical composition of glycoconjugates produced by tracheal goblet cells. The changes did not disappear even after 24-h recovery (Konrád ová et al. 2001). We decided to extend our experiments by the study evaluating the reaction of the epithelium of terminal bronchioles to the short-time inhalation of the same aerosol. We tried to compare the effect of the mineral water inhalation on the pseudostratified columnar ciliated tracheal epithelium, where secretory elements were represented by goblet cells, with the reaction of the simple columnar epithelium of distal airways containing secretory Clara cells. 


\section{Materials and Methods}

Six specified pathogen free (SPF) rabbits (New Zealand White, males, body weight 2,040 g - 3,080 g) were used. Three untreated rabbits served as controls. Three remaining animals were placed successively for $10 \mathrm{~min}$ into a plastic cage connected with the inhalation device PARI Master and nebuliser PARI LL (Pari GmbH, Starnberg, Germany, medium diameter of produced droplets $3.1 \mu \mathrm{m}$, total output $0.6 \mathrm{~g} / \mathrm{min}$ ). The rabbits inhaled an aerosol of mineral water for $10 \mathrm{~min}$. Chemical composition of this spring water is given in Tab. 1. Immediately after removal from the cage, animals were anaesthetised by i.v. administration of thiopental solution (Thiopental inj., VÚAB, Prague, Czech Republic) in dose $20 \mathrm{mg} / \mathrm{kg}$ b.w. Control animals were anaesthetised by the same method.

Table1

Chemical composition of the inhaled mineral water

\begin{tabular}{|l|c|l|l|l|l|l|c|}
\hline & $\mathrm{mg} / \mathrm{l}$ & & $\mathrm{mg} / \mathrm{l}$ & & $\mathrm{mg} / \mathrm{l}$ & & $\mathrm{mg} / \mathrm{l}$ \\
\hline $\mathrm{Li}^{+}$ & 13.48 & $\mathrm{Zn}^{2+}$ & 0.0023 & $\mathrm{Fe}^{\mathrm{II}}$ & 3.810 & $\mathrm{NO}_{2}^{-}$ & 0.00 \\
\hline $\mathrm{Na}^{+}$ & 3292.0 & $\mathrm{Cd}^{2+}$ & 0.000003 & $\mathrm{Co}^{2+}$ & 0.0003 & $\mathrm{NO}_{3}^{-}$ & 0.00 \\
\hline $\mathrm{K}^{+}$ & 160.5 & $\mathrm{Hg}$ & $<0.0001$ & $\mathrm{Ni}^{2+}$ & 0.0001 & $\mathrm{HPO}_{4}{ }^{2-}$ & 0.039 \\
\hline $\mathrm{NH}_{4}^{+}$ & 13.16 & $\mathrm{Al}$ & 0.359 & $\mathrm{U}^{\mathrm{II}}$ & $<0.0005$ & $\mathrm{HAsO}_{4}^{2-}$ & 0.003 \\
\hline $\mathrm{Cu}^{2+}$ & 0.0316 & $\mathrm{~Pb}^{2+}$ & 0.00008 & $\mathrm{~F}^{-}$ & 2.932 & $\mathrm{HCO}_{3}^{-}$ & 6010.0 \\
\hline $\mathrm{Be}^{2+}$ & 0.00157 & $\mathrm{~V}^{\mathrm{IV}}$ & 0.00370 & $\mathrm{Cl}^{-}$ & 2319.0 & $\mathrm{HBO}_{2}$ & 413.0 \\
\hline $\mathrm{Mg}^{2+}$ & 15.07 & $\mathrm{Cr}$ & 0.0016 & $\mathrm{Br}^{-}$ & 9.068 & $\mathrm{H}_{2} \mathrm{SiO}_{3}$ & 1.19 \\
\hline $\mathrm{Ca}^{2+}$ & 258.5 & $\mathrm{Mo}$ & 0.0001 & $\mathrm{I}^{-}$ & 8.993 & $\mathrm{CO}_{2}$ & 1984.0 \\
\hline $\mathrm{Sr}^{2+}$ & 5.245 & $\mathrm{UO}_{2}^{2+}$ & $<0.0005$ & $\mathrm{HS}^{-}$ & 0.00 & & \\
\hline $\mathrm{Ba}^{2+}$ & 11.02 & $\mathrm{Mn}^{2+}$ & 0.458 & $\mathrm{SO}_{4}^{2-}$ & 0.50 & & \\
\hline
\end{tabular}

In all animals, the thorax was opened as soon as possible, lungs were removed and immediately perfused by $5 \%$ glutaraldehyde in cacodylate buffer ( $\mathrm{pH} 7.2$ ). From one pulmonary lobe, tiny pieces of the tissue were collected, fixed for $90 \mathrm{~min}$ with the same fixative and then for $60 \mathrm{~min}$ with $2 \% \mathrm{OsO}_{4}$ in cacodylate buffer (pH 7.4). The material was dehydrated in graded series of alcohol and embedded in a Durcupan-Epon mixture. Terminal bronchioles were localised in semithin sections stained with toluidine blue. Ultrathin sections were prepared on Ultrotome Nova (LKB, Broma, Sweden), contrasted with uranyl acetate and lead citrate and examined in JEM 100 C electron microscope (Jeol, Tokyo, Japan).

For the quantitative evaluation, the total number of ciliated and Clara cells and the functional state of Clara cells were recorded in the electron microscope using the methods described in our previous paper (Uhlík 1996). In control rabbits and in rabbits after 10-min inhalation of mineral water aerosol, 601 and 355 epithelial cells were evaluated, respectively. To compare the results in both groups, the $\chi^{2}$ test of homogeneity in frequency tables was used. To specify categories causing deflections from the hypothesis of homogeneity, adjusted standardised deviations were employed.

Using the computer image analyser Lucia G (Laboratory Imaging, Prague, Czech Republic), details of Clara cells' cytoplasm were evaluated in digitalised electron micrographs. The supranuclear cytoplasm of randomly selected Clara cells was marked and measured. In this area, secretory granules and mitochondria were delineated, counted and automatically gauged. In control and experimental groups, $2,767.3 \mu \mathrm{m}^{2}$ and $2,093.2 \mu \mathrm{m}^{2}$ of Clara cells' cytoplasm with 426 and 430 granules and 2,172 and 2,260 mitochondria were analysed, respectively. The results were statistically evaluated by the two-group t-test and by its non-parametric analogy - Mann-Whitney test.

\section{Results}

1. The ultrastructure of the epithelium of terminal bronchioles in control rabbits

Terminal bronchioles of healthy control rabbits were lined by a simple epithelium where low columnar or cuboidal ciliated cells and high columnar Clara cells alternated almost regularly. In our previous paper, the arrangement and the ultrastructure of both types of the epithelial cells were described in detail (Uhlík 1996).

In the epithelium of the terminal bronchioles of healthy control rabbits, the Clara cells and the ciliated ones represented $52.7 \pm 3.6 \%$ and $47.3 \pm 3.6 \%$ of epithelial cells, respectively. In the majority of Clara cells $(73.5 \pm 9.4 \%)$, secretory granules were found. The average 
Table 2

Quantitative evaluation of the epithelium of terminal bronchioles and functional state of Clara cells in rabbits immediately after 10-min inhalation of mineral water aerosol (relative values)

\begin{tabular}{|l|c|c|}
\hline & Controls & Inhalation \\
\hline Ciliated cells $(\%)$ & $47.3 \pm 3.6$ & $* 39.2 \pm 2.5$ \\
\hline Clara cells $(\%)$ & $52.7 \pm 3.6$ & $* 60.8 \pm 2.5$ \\
\hline Clara cells with granules $(\%)$ & $73.5 \pm 9.4$ & $74.1 \pm 10.4$ \\
\hline Clara cells without granules $(\%)$ & $26.5 \pm 9.4$ & $25.9 \pm 10.4$ \\
\hline Number of granules per $1 \mu \mathrm{m}^{2}$ & $0.165 \pm 0.066$ & $0.217 \pm 0.092$ \\
\hline Area of granules $\left(\mu \mathrm{m}^{2}\right)$ & $0.149 \pm 0.042$ & $* 0.08 \pm 0.021$ \\
\hline Number of mitochondria per $1 \mu \mathrm{m}^{2}$ & $0.727 \pm 0.350$ & $* 0.118 \pm 0.0163$ \\
\hline Area of mitochondria $\left(\mu \mathrm{m}^{2}\right)$ & $0.219 \pm 0.077$ & 0.163 \\
\hline
\end{tabular}

$\mathrm{N}=3$, values are expressed as mean $\mathrm{SD}$, values designated $*$ differ significantly $(\alpha=0.05)$ from controls.

relative number of Clara cell secretory granules and mitochondria and their average area were given in Table 2.

2. The ultrastructure of the epithelium of terminal bronchioles in rabbits after 10-min inhalation of mineral water aerosol

Terminal bronchioles of the rabbits exposed to mineral water aerosol were still lined with the simple columnar epithelium composed of ciliated and Clara cells (Plate IV, Fig. 1). Apical junctional complexes were intact, intercellular spaces remained narrow and did not contain any free cells (Fig. 2). All epithelial cells widely rested on a well-developed basal lamina (Fig. 3).

Ciliated cells represented $39.2 \pm 2.5 \%$ of epithelial cells. This value differed significantly $(\alpha=0.05)$ from the corresponding value in control animals. Apical cytoplasmic protrusions that sometimes contained axonemes of degenerating cilia were found on their surfaces (Fig. 4). In deeper layers of cytoplasm of the ciliated cells, small vacuoles, dilated cisternae of Golgi complex, and relatively abundant secondary lysosomes were detected (Plate V, Fig. 5).

Remaining $60.8 \pm 2.5 \%$ of epithelial cells were the Clara cells $(\alpha=0.05)$. The appearance of their cytoplasm usually did not differ from the findings in control animals (Fig. 6). Isolated altered Clara cells were observed only exceptionally. In these cells, tubules of the smooth endoplasmic reticulum were widely dilated and filled with an electron-lucent content. However, mitochondria of such altered Clara cells revealed only mild signs of pathological alteration, their matrix was less electron-dense (Fig. 7).

Secretory granules of usual ultrastructure were found in $74.4 \pm 10.4 \%$ of Clara cells. Morphological signs of exocytosis were rarely observed. The granules were mostly situated in the apical portion of the cytoplasm, but not in direct contact with the cell membrane (Fig. 8). As the sign of possible apocrine mode of secretion, the secretory granules located in apical cytoplasmic protrusions were found exceptionally. The results of computer image analysis of Clara cell' s secretory granules and mitochondria are given in Table 2.

\section{Discussion}

In the terminal bronchioles of rabbit lungs, a tendency to raising proliferation of secretory Clara cells was ascertained after 10-min inhalation of the mineral water aerosol. Their relative count in the epithelium significantly increased $(\alpha=0.05)$ compared to that found in our control animals. The newly originating cells contained significantly smaller secretory granules and mitochondria in their cytoplasm $(\alpha=0.05)$. This proliferation was not accompanied by elevated liberation of the secretion stored in secretory granules. The 
number of Clara cells containing granules in their cytoplasm did not differ from the control values. Also the morphological signs of exocytosis were rarely observed (Uhlík et al. 2000). The number of secretory granules per $1 \mu \mathrm{m}^{2}$ of Clara cell cytoplasm even increased compared to controls. Nevertheless, this increase was not statistically significant. Only small fraction of Clara cells revealed signs of pathological alteration of their cytoplasm. However, marks of their complete degeneration, which were often described after the administration of many substances such as polycyclic aromatic compounds (naphthalene, 4-ipomeanol) (Plopper et al. 1992, 1994; Van Winkle et al. 1995, 1999; Lakritz et al. 1996), inhalation of trichloroethylene (Giovanetti et al. 1998), inhalation of ozone (Harkema et al. 1993), inhalation of domestic insecticides (Elia et al. 2000) or general administration of acetylcholine (Uhlík et al. 1999), were not observed.

In our previous study, the effect of 10-min inhalation of the same mineral water aerosol on the ultrastructure of the tracheal epithelium and on the composition of glycoconjugates produced by tracheal goblet cells was studied (Konrádová et al. 2001). We demonstrated that goblet cells were markedly influenced by this short-time inhalation. They were en bloc stimulated to release their secretion. After the instantaneous discharge, the cells again returned to the secretory cycle and gained an appearance of differentiating secretory elements. We observed also cells containing isolated, tiny, electron-dense granules. The proliferation of the stimulated secretory elements led to their hyperplasia with formation of intraepithelial mucous glands. During the histochemical study of glycoconjugates produced by goblet cells, we recorded a slight, but statistically significant $(\alpha=0.01)$ increase of cells containing acid sulphated glycoconjugates that was compensated by a decrease of cells containing acid sialylated ones. The cells containing glycoconjugates with terminal $\alpha(2-6)$-linked sialic acid to galactose, $\mathrm{N}$-acetylgalactosamine or O-glycans completely disappeared. Based on our previous studies, the absence of these glycoconjugates is regarded as a sign of overstimulation of goblet cells (V ajner et al. 2000).

As in the tracheal epithelium, the inhaled aerosol influenced mostly apical portions of ciliated cells of the epithelium of terminal bronchioles. They responded by the formation of apical cytoplasmic protrusions. This reaction was accompanied by degeneration of some free kinocilia. Similar reaction of the tracheal ciliated cells was described after inhalation of another substances such as bronchospasmolytic drugs (Konrádová et al. 1998). In deeper areas of the ciliated cell cytoplasm, only mild marks of the alteration were ascertained. We did not notice any signs of proliferation in this type of cells.

The epithelium of the terminal bronchioles was influenced and damaged by the single short-time inhalation of the mineral water aerosol. The reaction of the epithelium of terminal bronchioles was similar to that of the tracheal epithelium. In both epithelia, the secretory elements were stimulated to proliferate. Nevertheless, both epithelia differed in the level of stimulation of the secretory cells to release their secretion. Whilst the most tracheal goblet cells instantaneously released the content of their mucous granules, the secretion of Clara cells was not influenced by the treatment. The cells actually tended to store granules in their cytoplasm.

The inhalation of the aerosol of the studied water is used as a supplementary therapeutic method in the respiratory clinical practice. Our findings show that the homeostasis of the epithelium was damaged and admonishes to the heedfulness in the indication even of such seemingly harmless therapeutic procedures.

\section{Ultrastruktura epitelu terminálních bronchiolů králíků po inhalaci aerosolu minerální vody}

Inhalace aerosolu minerální vody je běžnou doplňkovou metodou léčby chronických respiračních onemocnění. Rozhodli jsme se proto v návaznosti na předchozí experimenty hodnotící vliv krátkodobé inhalace tohoto aerosolu na epitel trachey zhodnotit také reakci 
epitelu distálních úseků dýchacích cest - terminálních bronchiolů. Nechali jsme laboratorní králíky 10 min inhalovat aerosol minerální vody a materiál pro elektronově mikroskopické vyšetření jsme odebírali ihned po inhalaci. Kvantitativně jsme hodnotili ultrastrukturu epitelu terminálních bronchiolů, zvláště jsme se zaměřili na hodnocení změn cytoplazmy sekrečních Clara buněk, kde jsme použili počítačovou analýzu obrazu. Stejně jako u kontrolních králíků lemoval po desetiminutové inhalaci aerosolu minerální vody terminální bronchioly králíků jednovrstevný cylindrický epitel obsahující řasinkové a Clara buňky. Na apikálních površích řasinkových buněk jsme pozorovali tvorbu cytoplazmatických protruzí, jež někdy vedla $\mathrm{k}$ zániku volných kinocilií. V hlubších oblastech jejich cytoplazmy jsme pozorovali mírné známky patologické alterace. U sekrečních Clara buněk jsme pozorovali tendenci k zvýšené proliferaci. Tato proliferace nebyla doprovázena zvýšeným vylučováním sekretu střádaného v sekrečních granulech. Jen velmi malá část Clara buněk jevila známky patologické alterace cytoplazmy, nepozorovali jsme však jejich degeneraci. Nálezy patologické alterace cytoplazmy epitelových buněk a jejich zvýšené proliferace vypovídají o nefyziologickém zásahu do homeostázy epitelu a nabádají k obezřetné indikaci i takto jednoduchých a zdánlivě neškodných terapeutických opatř̌ení.

\section{Acknowledgement}

This work was supported by the research project No. 111300003 of Ministry of Education of the Czech Republic.

\section{References}

ELIA, J, AOKI, A, MALDONADO, CA 2000: Response of bronchiolar Clara cells induced by a domestic insecticide. Analysis of CC10 kDa protein content. Histochem. Cell Biol 113: 125-133

GIOVANETTI, A, ROSSI, L, MANCUSO, M, LOMBARDI, CC, MARASCO, MR, MANNA, F, ALTAVISTA, P, MASSA, EM 1998: Analysis of lung damage induced by trichloroethylene inhalation in mice fed diets with low, normal, and high copper content. Toxicol Pathol 26: 628-635

HARKEMA, JR, PLOPPER, CC, HYDE, DM, ST GEORGE, JA, WILSON, DW, DUNGWORTH, DL 1993: Response of macaque bronchiolar epithelium to ambient concentrations of ozone. Am J Pathol 143: 857-866

KONRÁDOVÁ, V, UHLÍK, J, VAJNER, L, ZOCOVÁ, J 1998: The effect of two $\beta_{2}$-adrenergic agonists on the ultrastructure of the airway epithelium in rabbits. Vet Med - Czech 43: 187-192

KONRÁDOVÁ, V, VAJNER, L, UHLÍK, J, ZOCOVÁ, J 2001: Changes in tracheal epithelium during 24 hours after inhalation of mineral water. Acta Vet Brno 70: 167-172

LAKRITZ, J, CHANG, A, WEIR, A, NISHIO, S, HYDE, D, PHILPOT, R, BUCKPITT, AR, PLOPPER, CG 1996 : Cellular and metabolic basis of Clara cell tolerance to multiple doses of cytochrome P450-activated cytotoxicants. I: Bronchiolar epithelial reorganization and expression of cytochrome P450 monoxygenases in mice exposed to multiple doses of naphthalene. J Pharmacol Exp Ther 278: 1408-1418

PLOPPER, CG, MACKLIN, J, NISHIO, SJ, HYDE, DM, BUCKPITT, AR 1992: Relationship of cytochrome P450 activity to Clara cells cytotoxicity. III. Morphometric comparison of changes in the epithelial populations of terminal bronchioles and lobar bronchi in mice, hamsters, and rats after parenteral administration of naphthalene. Lab Invest 67: 553-565

PLOPPER, CG, WEIR, AJ, NISHIO, SJ, CHANG, A, VOIT, M, PHILPOT, RM, BUCKPITT, AR 1994: Elevated susceptibility to 4-ipomeanol cytotoxicity in immature Clara cells of neonatal rabbits. J Pharmacol Exp Ther 269: 867-880

UHLÍK, J 1996: Quantitative evaluation of findings in the epithelium of terminal bronchioles in healthy rabbits (Oryctolagus cuniculus var. edulis). Acta Vet Brno 65: 181-184

UHLÍK, J, KONRÁDOVÁ, V, VAJNER, L, ZOCOVÁ, J 1999: Ultrastructure of the epithelium of terminal bronchioles in rabbits after the administration of acetylcholine. Acta Vet Brno 68: 179-184

UHLÍK, J, KONRÁDOVÁ, V, VAJNER, L, ZOCOVÁ, J 2000: Effects of epinephrine administration on epithelial ultrastructure of terminal bronchioles in rabbits. Acta Vet Brno 69: 261-266

VAJNER, L, UHLÍK, J, KONRÁDOVÁ, V,ZOCOVÁ, J 2000: The effect of intravenously administered acetylcholine on the glycoconjugate composition in goblet cells of the tracheal epithelium in rabbits. Acta Vet. Brno 69: 17-23

VAN WINKLE, LS, BUCKPITT, AR, NISHIO, SJ, ISAAC, JM, PLOPPER, CG 1995: Cellular response in naphthalene-induced Clara cell injury and bronchiolar epithelial repair in mice. Am J Physiol 269: L800-L818

VAN WINKLE, LS, JOHNSON, ZA, NISHIO, SJ, BROWN, CD, PLOPPER, CG 1999: Early events in naphthalene-induced acute Clara cell toxicity: comparison of membrane permeability and ultrastructure. Am J Respir Cell Mol Biol 21: 44-53

VASKIVSKYJ, M 1968: Effect of inhalation therapy with Bílina mineral water on self-cleaning ability of the mucous membrane of the upper respiratory tract (in Czech). Fysiatr Revmatol Vestn 46: 301-304 
Plate IV

Uhlík J. et al.: Ultrastructure... pp. 283-288
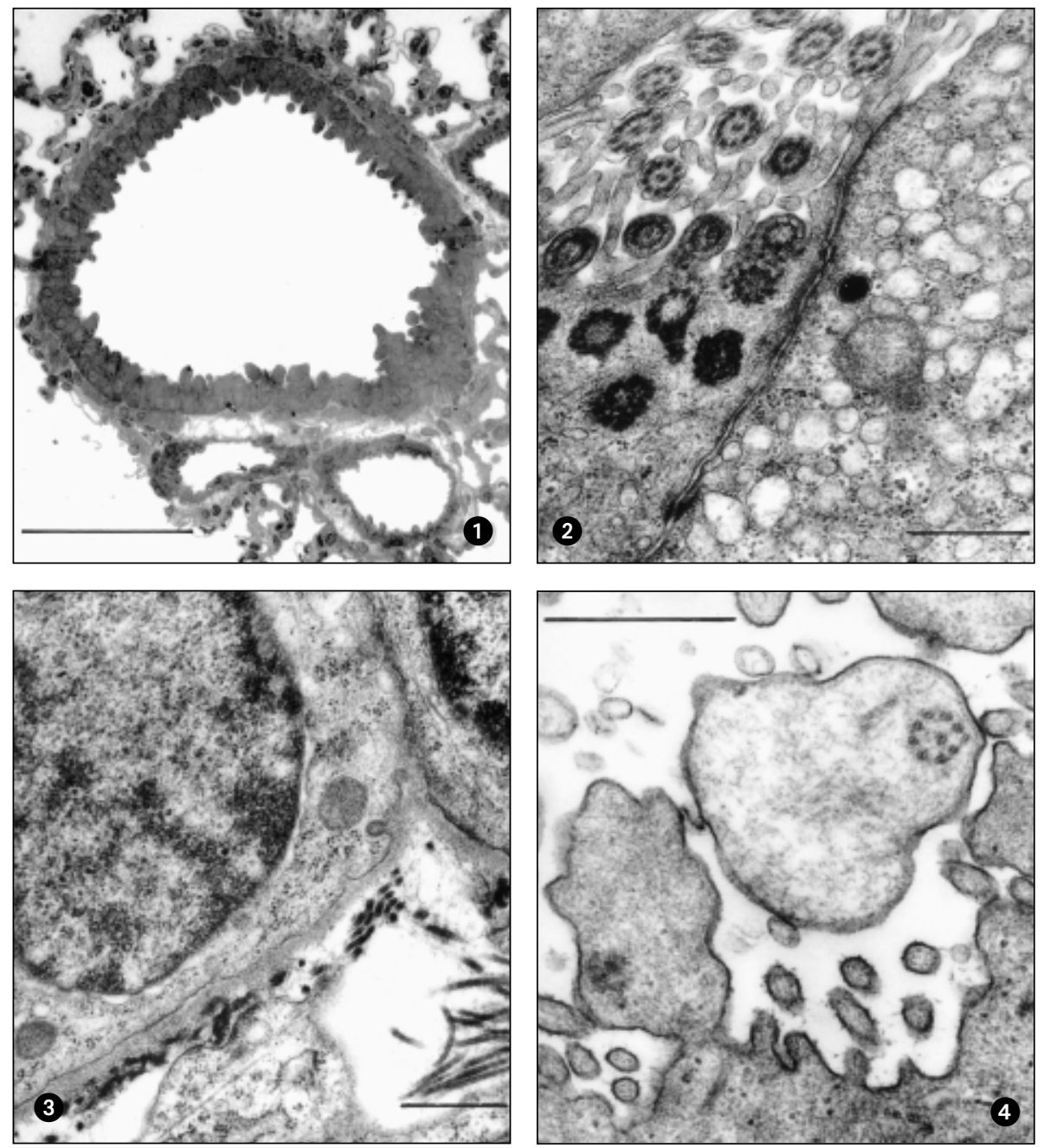

Fig. 1: Transverse section of a terminal bronchiole lined with simple epithelium composed of lower ciliated cells and higher Clara cells. Rabbit, 10-min inhalation of mineral water aerosol, light microscopy, semithin section, bar $=100 \mu \mathrm{m}$.

Fig. 2: Intact apical junctional complex between a ciliated cell and an altered Clara cell. Rabbit, 10-min inhalation of mineral water aerosol, electron microscopy, bar $=0.5 \mu \mathrm{m}$.

Fig. 3: Basal portions of 2 epithelial cells resting on a well developed basal lamina. Rabbit, 10-min inhalation of mineral water aerosol, electron microscopy, bar $=0.5 \mu \mathrm{m}$.

Fig. 4: Cytoplasmic protrusions on the apical surface of a ciliated cell. One of them contains an axoneme of a disintegrating cilium. Rabbit, 10-min inhalation of mineral water aerosol, electron microscopy, bar $=0.5 \mu \mathrm{m}$. 
Plate V
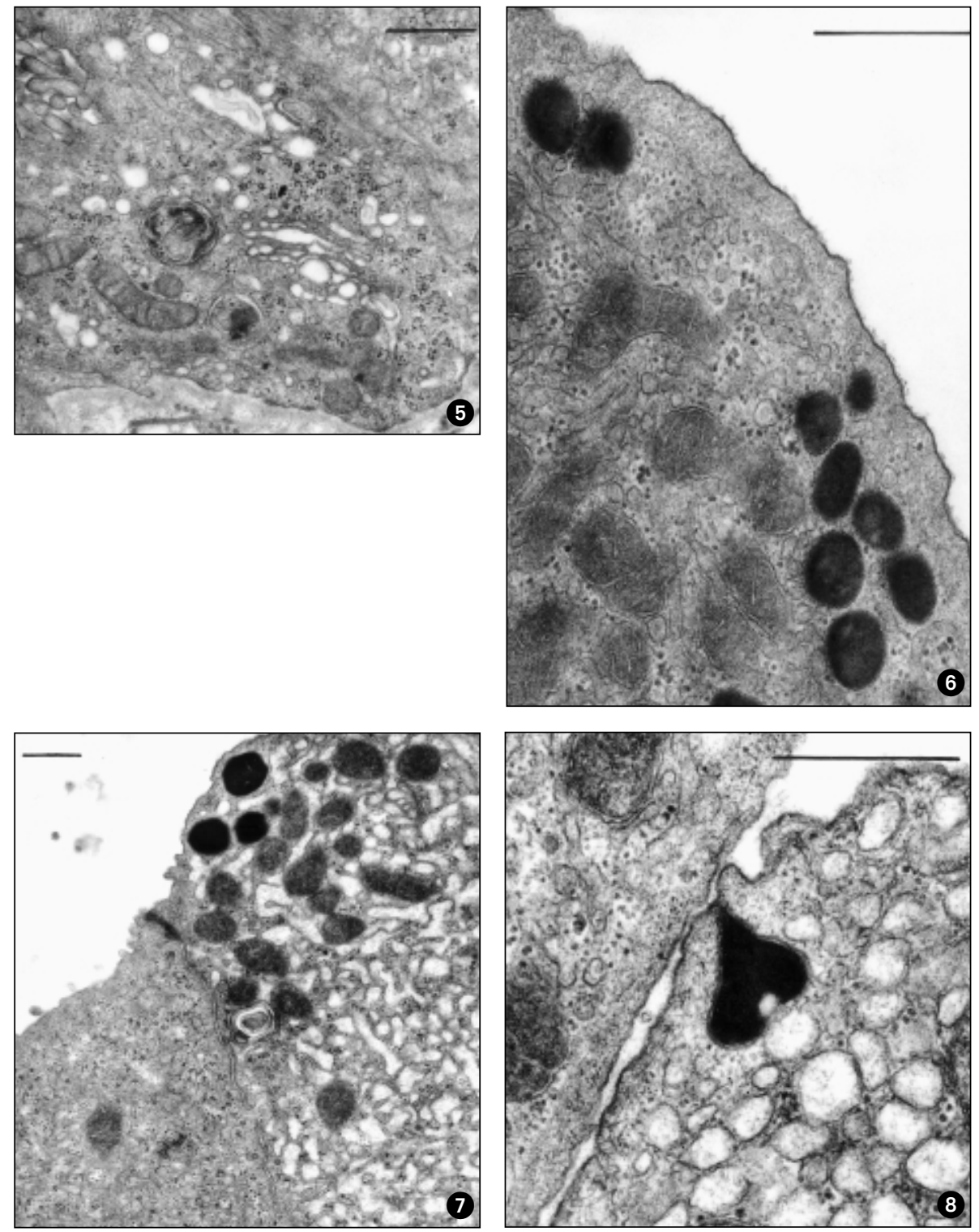

Fig. 5: Secondary lysosomes and dilated Golgi complex in the cytoplasm of a ciliated cell. Rabbit, 10-min inhalation of mineral water aerosol, electron microscopy, bar $=0.5 \mu \mathrm{m}$.Fig. 6: Secretory granules, mitochondria and narrow tubules of smooth endoplasmic reticulum in the intact cytoplasm of a Clara cell. Rabbit, 10-min inhalation of mineral water aerosol, electron microscopy, bar $=0.5 \mu \mathrm{m}$.

Fig. 7: Dilated tubules of smooth endoplasmic reticulum, secondary lysosome and intact mitochondria in the cytoplasm of an altered Clara cell. Rabbit, 10-min inhalation of mineral water aerosol, electron microscopy, bar $=0.5 \mu \mathrm{m}$.

Fig. 8: Secretory granule situated closely to the plasma membrane of an altered Clara cell. Rabbit, 10-min inhalation of mineral water aerosol, electron microscopy, bar $=0.5 \mu \mathrm{m}$ 